\title{
Physiological effects of phyto-oestrogens in relation to cancer and other human health risks
}

\author{
BY AEDIN CASSIDY* \\ Nutritional Chemoprevention and Gut Metabolism Group, Medical Research Council, \\ Dunn Clinical Nutrition Centre, Hills Road, Cambridge CB2 2DH
}

\section{Effets physiologiques des phytoestrogènes en relation avec le cancer et autres risques sur la santé de l'homme}

\section{RÉSUMÉ}

Les aliments d'origine végétale contiennent des phytoestrogènes dont la structure est semblable à l'oestrogène des mammifères, l'estradiol-17 $\beta$. Ils ont une affinité pour les récepteurs de l'oestrogène entre $1 / 500$ et 1/1000 comparée à celle de l'oestrogène-17 $\beta$, et ils produisent des réponses oestrogéniques typiques et prévisibles lorsqu'ils sont administrés aux animaux. Dans les modèles animaux et dans les systèmes expérimentaux in vitro, les phytoestrogènes se montrent capables d'agir à la fois comme agonistes partiels et comme antagonistes partiels, avec des effets primaires favorisés par la compétition avec l'estradiol-17 $\beta$ pour le récepteur de l'oestrogène.

Les isoflavones, administrés comme produits de protéine de soja, ont modifié le statut hormonal et la régulation physiologique du cycle menstruel chez des femmes avant la ménopause. Aucun de ces changements n'a été observé lorsque le soja a été remplacé par de l'Arcon $F$, un produit de soja sans isoflavone. Ces résultats suggèrent donc que les oestrogènes végétaux présents dans le soja exercent potentiellement un effet oestrogénique faible sur l'axe hypothalamique-pituitaire-gonadique. Il est possible que l'état de conjugaison des isoflavones de l'alimentation influence les effets physiologiques observés, les isoflavones inconjugués étant potentiellement plus efficaces. Dans des essais en appartement métabolique sur des femmes ménopausées, on a observé que 60 $\mathrm{g}$ /jour de soja sur une période de quatre semaine supprimaient les niveaux de luteinizing hormone (LH), alors que $40 \mathrm{~g} / \mathrm{jour}$ de graine de lin (une riche source de lignanes) sur une période de six semaines causaient une suppression significative de LH aussi bien que de follicle-stimulating hormone.

Il est possible que les modifications hormonales et du cycle menstruel induites par la protéine de soja et la graine de lin sur les femmes avant et après la ménopause soient potentiellement bénéfiques au regard des facteurs de risque du cancer du sein. Des preuves épidémiologiques, des résultats d'études sur des animaux, et certains travaux in vitro suggèrent également que les phytoestrogènes pourraient avoir un rôle protecteur dans le développement du cancer du sein. Les données expérimentales des études sur le rôle protecteur exercé par les phytoestrogènes dans la prévention du cancer de la prostate sont moins convaincantes.

Il est évident que ces composés sont absorbés, mais il y a une grande variabilité individuelle dans leur métabolisme. Des travaux plus approfondis devraient chercher à étudier le métabolisme des phytoestrogènes in vivo pour expliquer la grande variabilité individuelle dans l'excrétion de ces composés.

* Present address: School of Biological Sciences, University of Surrey, Guildford GU2 5XH. 
Il est nécessaire de mesurer les effets indésirables de phytoestrogènes lorsqu'ils sont consommés à des concentrations naturelles dans l'alimentation. Les effets physiologiques des phytoestrogènes peuvent également avoir des effets bénéfiques sur le métabolisme osseux et la maladie ischémique de coeur, mais ces hypothèses demandent une étude approfondie.

Edible plant material contains numerous weakly oestrogenic diphenolic compounds, termed phyto-oestrogens. Fig. 1. shows the major classes of phyto-oestrogens, which are the isoflavones, lignans, coumestans and resorcyclic acid lactones. Most work on the effects of phyto-oestrogens in relation to human health has centred on the isoflavones and lignans.

\section{STRUCTURE AND SOURCES}

Isoflavones are intrinsic plant compounds, the amount present being dependent on many factors, including those associated with growth (Hanson et al. 1965) and genetic background (Morley \& Francis, 1968). Concentrations may be increased as a direct response to microbial or insect damage and it has been speculated that these diphenols possess anti-fungal activity (Naim et al. 1974). They are associated also with flower pigments (Clevenger, 1964) and play a role in lignification (Francis \& Hume, 1971). Lignans are widely distributed as minor constituents of some plant species (Haworth \& Slinger, 1940), and are defined as compounds possessing a 2,3-dibenzylbutane structure (Rao, 1978). The mammalian lignans, enterodiol and enterolactone, differ significantly in chemical structure from plant lignans in that they have a phenolic hydroxyl group substituted on the meta position of the aromatic ring (Setchell et al. 1981).

Several plants contain high concentrations of phyto-oestrogens; for example, linseed (or flaxseed) is a rich source of the lignan precursor, secoisolariciresinol, while soyabean-protein products contain high concentrations of isoflavones (Table 1; Price \& Fenwick, 1985). Phyto-oestrogens occur naturally in plants either as highly-polar glycoside conjugates, or in the unconjugated form; for example, textured vegetable
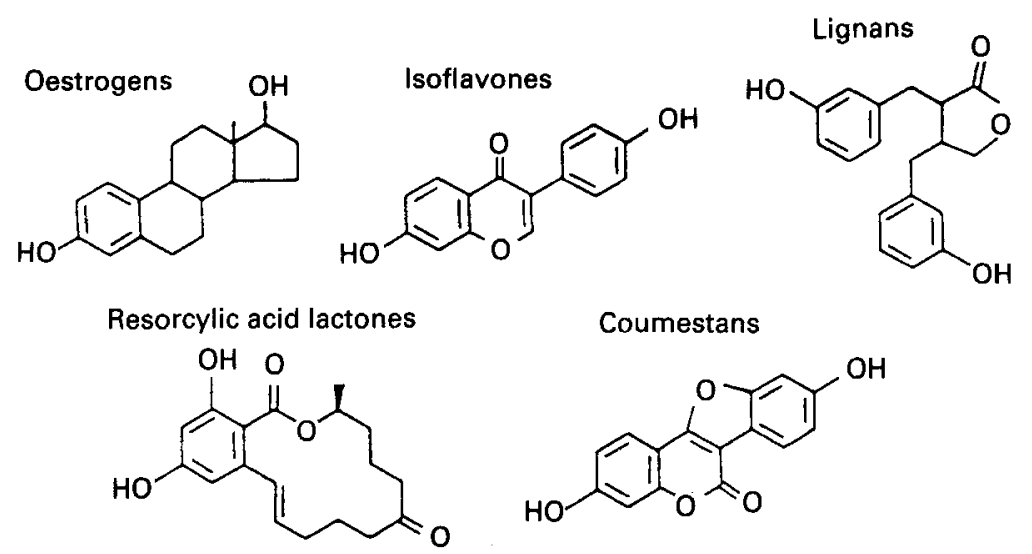

Fig. 1. Common classes of phyto-oestrogens. 
Table 1. Total isoflavone and lignan concentrations in foods ( $\mu \mathrm{g} / \mathrm{g})$

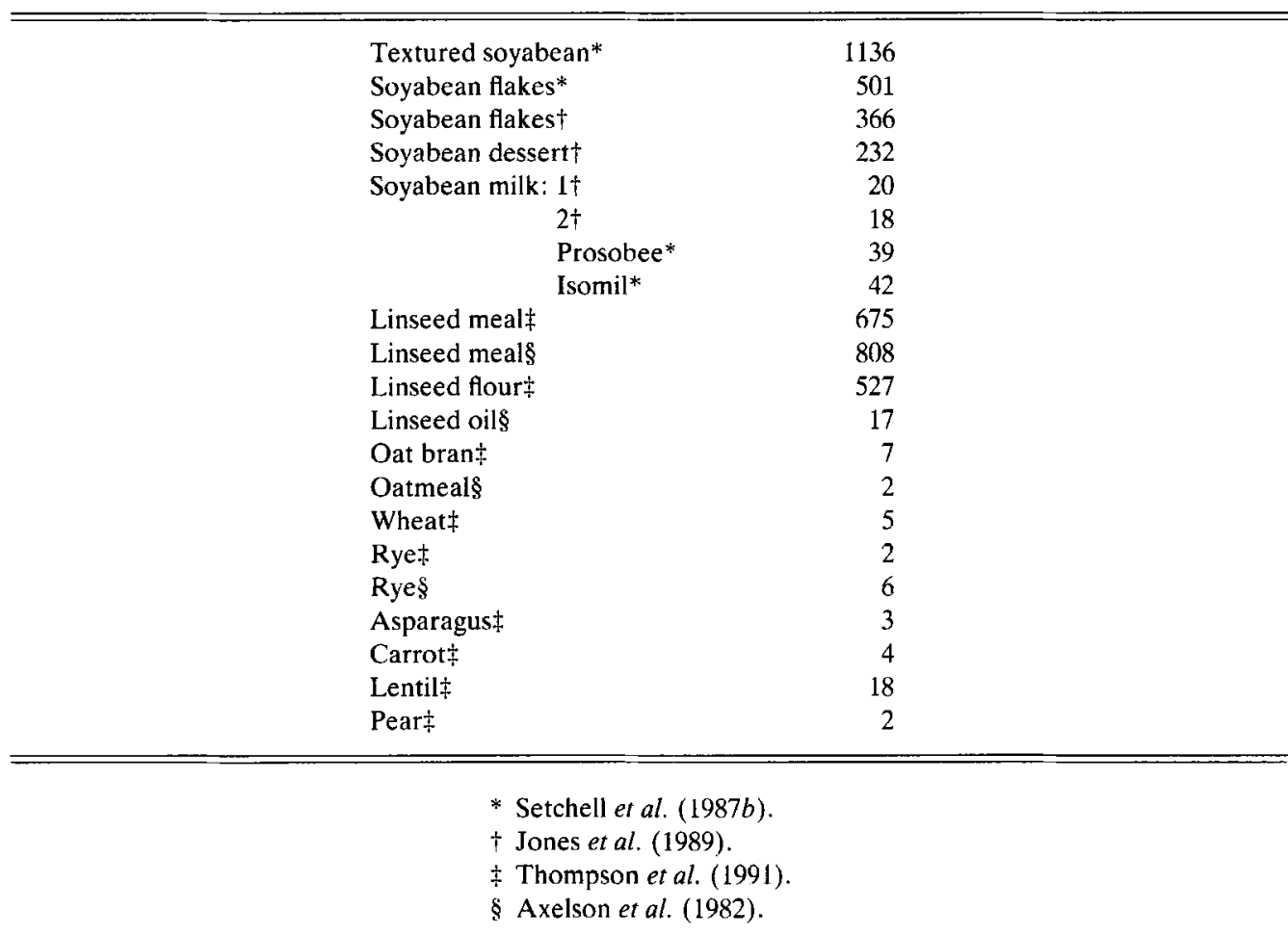

protein (TVP) and tofu (soyabean curd) contain high levels of conjugated isoflavones, such as daidzin and genistin, while in fermented soyabean products such as miso, approximately $90 \%$ of the isoflavones are present in the unconjugated form, e.g. daidzein and genistein (Coward et al. 1993). When ingested, these compounds are metabolized by the bacteria in the large gut to form equol (Setchell et al. 1984).

\section{OESTROGENICITY}

These heterocyclic phenols are structurally similar to the mammalian oestrogen, oestradiol-17 $\beta$. A common chemical characteristic of these compounds is the presence of a phenolic ring, a prerequisite for binding to the oestrogen receptor. The principal compounds within these classes of phyto-oestrogens have been shown to have weak oestrogenic activity, ranging from $1 / 500$ to $1 / 1000$ the activity of oestradiol-17 $\beta$, and to produce typical and predictable oestrogenic responses when administered to animals (Shutt \& Cox, 1972; Martin et al. 1978; Verdeal et al. 1980; Juniewicz et al. 1988). Oestrogenic compounds can be agonistic or antagonistic to oestradiol-17 $\beta$ when they act simultaneously at target tissues. Antagonistic compounds normally compete for oestradiol- $17 \beta$ receptors but fail to stimulate the nucleus to respond fully. This partial oestrogen agonistic and/or antagonistic behaviour is a common feature of many weak oestrogens (Jordan, 1990). In animal models and in vitro experimental systems the isoflavones appear to act as anti-oestrogens, with primary anti-oestrogenic effects mediated via competition with oestradiol- $17 \beta$ for the oestrogen receptor. 
These compounds are weak oestrogens; the activity of genistein, for example, is 1000-fold less than that of oestradiol (Shutt \& Cox, 1972). However, certain foods contain comparatively large amounts so that urinary excretion and plasma concentrations may exceed levels of endogenous oestrogens by several orders of magnitude (Table 2). Urinary excretion of the principal oestrogen, oestrone glucuronide, ranges between 2 and $27 \mu \mathrm{g} / \mathrm{d}$ during the menstrual cycle (Setchell, 1985), while the excretion of isoflavones on $60 \mathrm{~g}$ TVP diet/d was $0.4-7.5 \mathrm{mg} / \mathrm{d}$ (Cassidy et al. 1994).

\section{EPIDEMIOLOGY}

Soyabean consumption is higher in countries where the risk of hormone-dependent cancers is low. Cross-sectional studies which have measured urinary excretion of phyto-oestrogens show that urinary isoflavone (daidzein, genistein and equol) excretion is substantially greater in Japanese volunteers consuming a traditional diet compared with levels in adults living in Boston and Helsinki (Table 2). The limited plasma data that are currently available also suggest that levels of biologically-active isoflavones (free and sulphate fraction) are ten to twenty times higher in Japanese men than in Finnish males (Table 2). Urinary lignan (enterodiol and enterolactone) excretion is higher in vegetarian subjects than in those consuming an omnivorous diet (Table 2 ). In addition, recent data from Adlercreutz et al. (1995), show that faecal excretion of phytooestrogens is substantially higher in vegetarian subjects than in a group of omnivores (Table 2).

The incidence of breast cancer and prostate cancer in countries of the Western world is significantly greater than that in Oriental countries, where the incidence of developing the disease is 5-8-fold less (Muir et al. 1987). However, the incidence of breast and prostate cancer in Asian migrants and their offspring approaches the incidence rates of indigenous Westerners (Muir et al. 1987). These findings indicate that the majority of hormone-dependent cancers occur as a result of environmental influences, probably diet, and that they are potentially preventable.

The differences in breast-cancer incidence rates between Asian populations and Western countries may possibly be related to the action of phyto-oestrogens as protective agents in the diet. British intake of one class of phyto-oestrogens, the isoflavones, has been estimated to be $<1 \mathrm{mg} / \mathrm{d}$ (Jones et al. 1989), while the average consumption of these compounds in Asian countries is $50-100 \mathrm{mg} / \mathrm{d}$ (Barnes et al. 1990; Adlercreutz et al. 1991a; Coward et al. 1993). Table 2 shows that Japanese excrete up to twenty times more equol in urine than Western populations, and have higher circulating levels of isoflavones in plasma than Western populations (Table 2).

Table 3 shows that three of five epidemiological trials have reported a protective effect of soyabean products against the development of breast cancer. In the two prospective trials, Nomura et al. (1978) found an inverse association between intake of miso soup (a fermented soyabean paste), and a trend toward an inverse association between intake of tofu (a soyabean curd), and subsequent risk of breast cancer. Hirayama (1986) also showed that a high intake of soyabean-paste soup was associated with a reduced risk in Japanese women. One case-control study (Lee et al. 1991) found a significant inverse association in premenopausal women between breast cancer risk and soyabean-protein intake, although two other case-control studies found no relationship (Table 3).

Table 3 shows that there is less consistency between soyabean consumption and risk of prostate cancer. In one Japanese study. there was no significant association between 
soyabean-paste soup and prostate cancer risk, although protective effects were observed for leafy green vegetables (Hirayama, 1979). In addition, Oishi et al. (1988) found no significant relationship between intake of miso soup and prostate cancer when they compared cancer patients with patients with hyperplastic disease and hospital controls. Severson et al. (1989) showed a trend towards a protective effect with tofu, but no effect with miso soup in a group of 7999 men in Hawaii followed for almost 20 years. In this study the number of subjects with the highest intake was small and the association reached only borderline significance $(P=0.054)$.

\section{ANIMAL STUDIES}

In the last 50 years, several important examples of the way in which dietary intake of phyto-oestrogens can influence reproductive physiology in animals have been reported. The earliest documented example was the recognition of an infertility syndrome in sheep, referred to as 'clover disease' (Bennetts et al. 1946; Shutt, 1976). This condition resulted from ewes grazing on pastures rich in Trifolium subterraneum, a species of clover rich in the isoflavone precursor, formononetin. The intestinal metabolism of this isoflavone leads to the formation of equol, and this weak oestrogen is absorbed and attains high circulating concentrations that subsequently cause permanent histological damage to the ovaries and uterus of the animal.

Setchell et al. (1987a) showed that the addition of soyabean protein to the commercial diet of the captive cheetah (Acinonyx jubatus) was the cause of infertility and veno-occlusive liver disease. The effectiveness of isoflavones in the cheetah is explained by the poor capacity of the feline liver to conjugate steroids with glucuronic acid, an important route of deactivation. As a result, the unconjugated isoflavones predominate in the circulation.

Compounds in soyabean also appear to be active in animal models of breast cancer. Hawrylewicz et al. (1991) showed that soyabean-protein isolate decreased tumours by $50 \%$ in an N-methyl-N-nitrosourea (NMU) model of breast cancer. Troll et al. (1980) showed a $50 \%$ reduction in experimentally-induced X-ray irradiated mammary tumours in rats consuming a powdered soyabean diet. More recently, Barnes et al. (1990) showed that soyabean ingestion led to a reduction in mammary tumour growth in both the NMU and the dimethyl-benz $(\alpha)$ anthracene rat models of breast cancer. In these models, tumour formation was negatively correlated with total dietary isoflavone concentrations and, in particular, with dietary intake of genistein and urinary isoflavone excretion levels. In addition, the results from a follow-up study found that a soyabean product from which the isoflavones had been chemically removed (Arcon F) had no effect on mammary carcinogenesis (Barnes et al. 1990), again providing evidence that isoflavones exert anti-oestrogenic effects in vivo.

More recently, Lamartiniere et al. (1995) showed that administration of genistein to rats in the perinatal period was sufficient to cause a marked latency in the appearance of mammary tumours after administration of 7,12-dimethylbenz $(\alpha)$ anthracene at $50 \mathrm{~d}$ of age.

Only limited data on the effects of soyabean on prostate cancer induced in animal models are available. Sharma et al. (1992) showed in a rat model that a soyabean diet reduced the severity and incidence of prostatitis in the lateral lobe of the prostate. Soyabean appears to exert anti-oestrogenic effects in neonatally-oestrogenized mice. A 


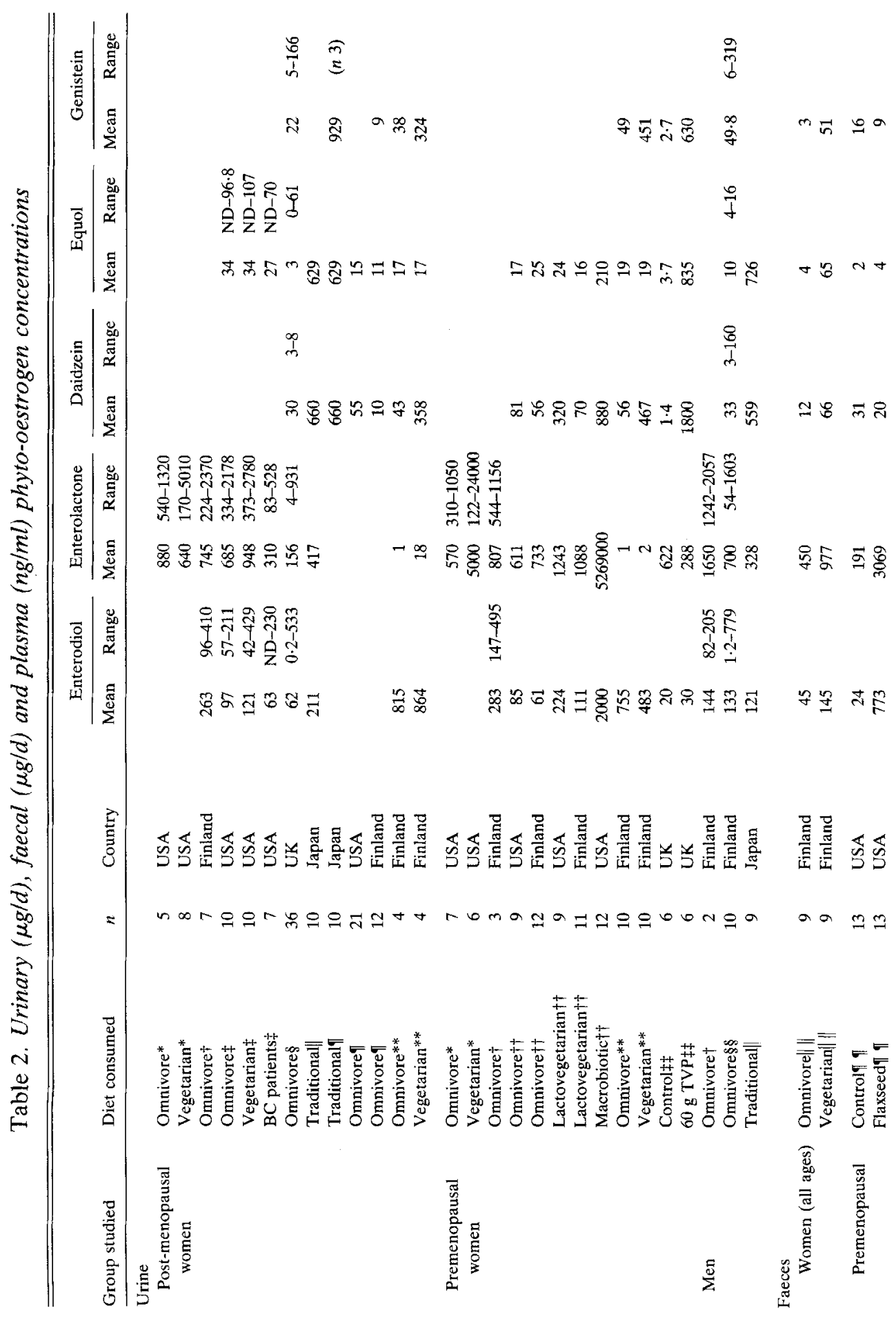




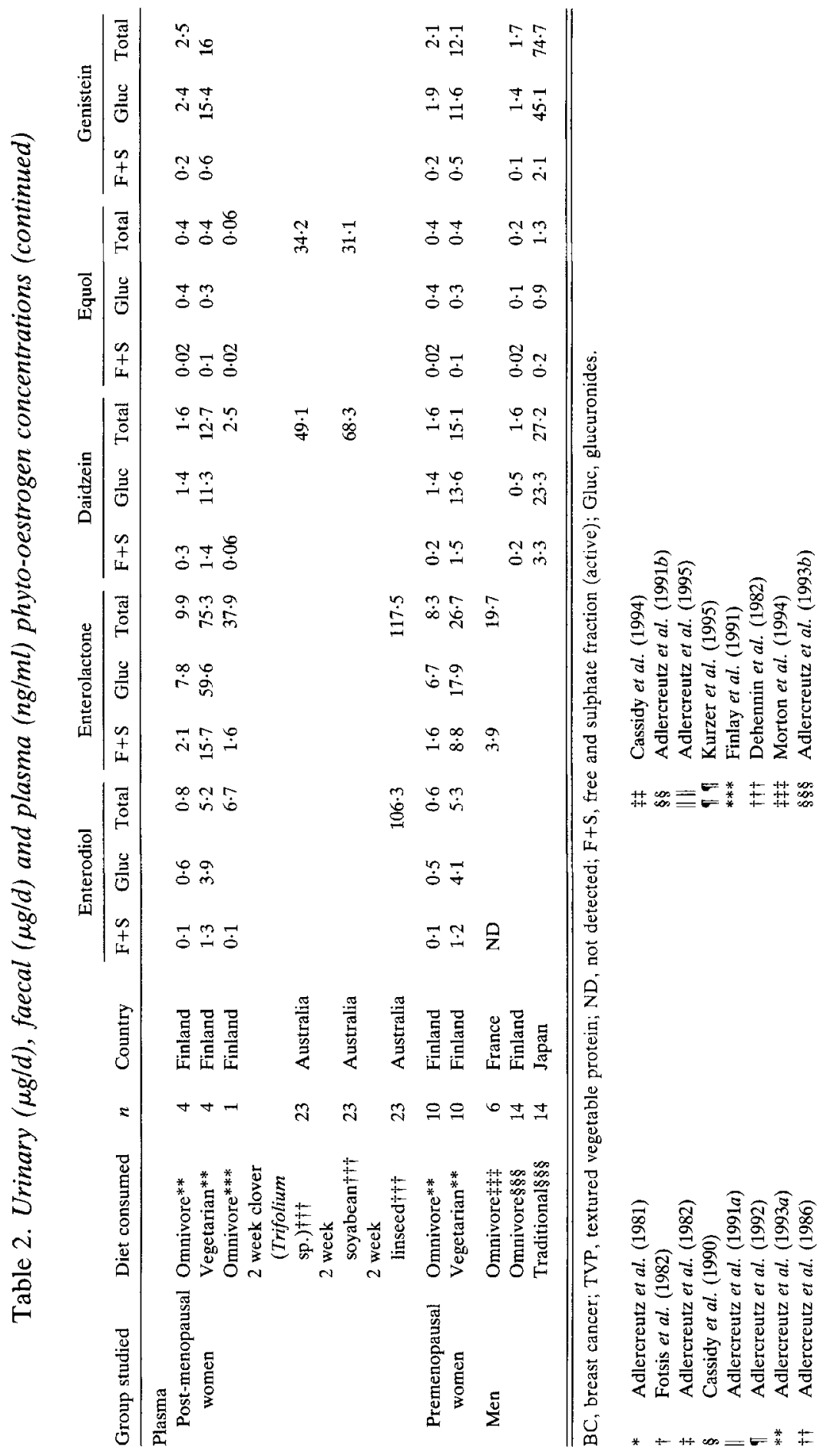


Table 3. Epidemiological studies examining the role of soyabean products in breast and prostate cancer risk (Adapted from Messina et al. 1994)

\begin{tabular}{|c|c|c|c|c|}
\hline Study & Soyabean product & $\begin{array}{l}\text { Estimate of } \\
\text { relative risk }\end{array}$ & Findings & Reference \\
\hline \multicolumn{5}{|l|}{ Breast cancer } \\
\hline Case-control & Soyabean & NC & NS & Hirohata et al. (1985) \\
\hline \multirow[t]{2}{*}{ Prospective } & Miso soup & $\mathrm{NC}$ & Decreased risk* & Nomura et al. (1978) \\
\hline & Tofu & $\mathrm{NC}$ & Decreased risk* & \\
\hline Prospective & Miso soup & $0 \cdot 46$ & Decreased risk & Hirayama (1986) \\
\hline \multirow[t]{2}{*}{ Case-controlt } & Soyabean protein & $0 \cdot 43$ & Decreased risk & Lee et al. $(1990)$ \\
\hline & Soyabean: total protein & $0 \cdot 29$ & Decreased risk & \\
\hline \multirow[t]{2}{*}{ Case-control } & Soyabean protein & $1 \cdot 0$ & No change in risk & Yuan et al. (1995) \\
\hline & Soyabean: total protein & $1 \cdot 0$ & No change in risk & \\
\hline \multicolumn{5}{|l|}{ Prostate cancer } \\
\hline Cohort & Miso soup & $0 \cdot 76$ & NS & Hirayama (1979) \\
\hline \multirow[t]{2}{*}{ Case-control } & Miso soup & $1 \cdot 29$ & $\begin{array}{l}\text { NS (cancer patients } \\
v \text {. benign condition) }\end{array}$ & Oishi et al. (1988) \\
\hline & & $0 \cdot 64$ & $\begin{array}{l}\text { NS (cancer patients } \\
v . \text { hospital controls) }\end{array}$ & \\
\hline \multirow[t]{2}{*}{ Cohort } & Tofu & $0 \cdot 35$ & $\mathrm{NS}(P=0.054)$ & Seversen et al. (1989) \\
\hline & Miso soup & $1 \cdot 24$ & NS & \\
\hline
\end{tabular}

$\mathrm{NC}$, could not be calculated.

* Decreased risk was significant only for baseline period 1971-1975.

$\dagger$ Premenopausal only.

soyabean diet reduced the prostatic growth inhibition due to diethylstilbestrol and, in preliminary studies, delayed the development of dysplastic changes in the prostate (Makela et al. 1995). However, the homology between this animal model and human prostatic cancer remains to be established.

\section{MECHANISMS OF ACTION AND METABOLISM}

On ingestion the phyto-oestrogen conjugates daidzin and genistin are hydrolysed in the large gut under the action of intestinal bacteria (Setchell et al. 1984) to release the unconjugated daidzein and genistein. The extent of absorption may be dependent on the chemical form of the isoflavones, in that the unconjugated isoflavones, because of their amphiphilic properties, may be more readily absorbed and, therefore, more bioavailable than the highly-polar conjugated species. The isoflavone metabolite, equol, is thought to be derived from isoflavone precursors.

Absorbed phyto-oestrogens are transported to the liver via the hepatic portal vein, where they are rapidly conjugated with glucuronic acid, and to a much lesser extent with sulphuric acid, by the liver (Axelson \& Setchell, 1980; Setchell et al. 1981, 1984; Fig. 2). Thus, in both blood and urine, phyto-oestrogens are found primarily as conjugates. In plasma, the free and sulphate fractions are biologically active, while the glucuronide fraction is considered to be biologically inactive (Adlercreutz et al. 1993a). In faeces, phyto-oestrogens are predominantly found in the unconjugated form, with less than $10 \%$ present in the conjugated state (Fig. 2). Quantification of phyto-oestrogens in biological 


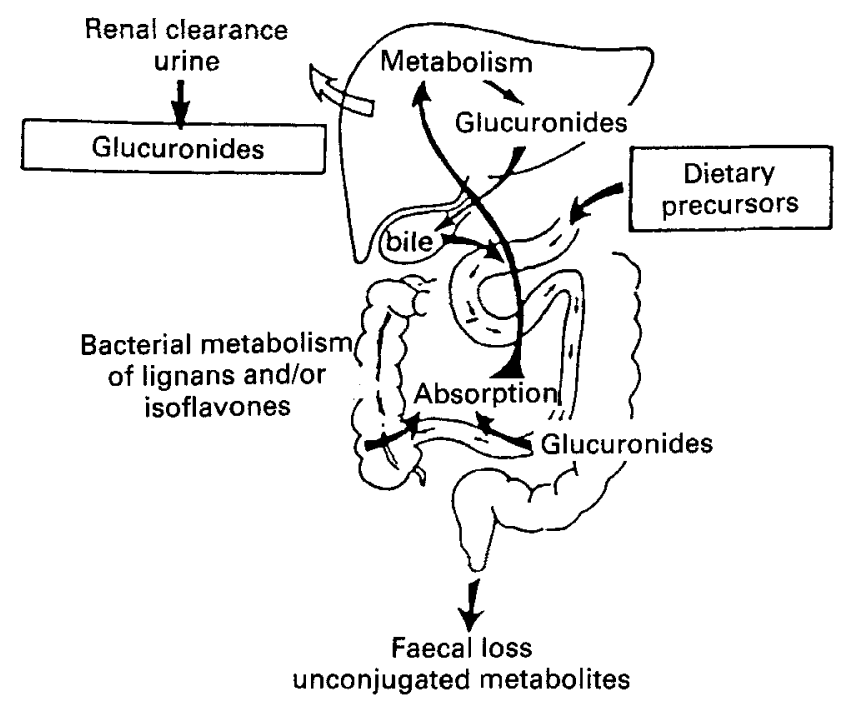

Fig. 2. Physiology of phyto-oestrogens.

fluids is generally performed by gas chromatography-mass spectrometry, following extensive extraction, hydrolysis, and derivatization of the compounds (Setchell et al. 1983; Adlercreutz et al. 1993a).

Under controlled conditions, Cassidy et al. (1994) showed that a challenge of $45 \mathrm{mg}$ conjugated isoflavones/d, as $60 \mathrm{~g}$ TVP/d over a complete menstrual cycle, resulted in a 1000 -fold increase in isoflavone excretion (Table 1). Total urinary isoflavone levels ranged from 1 to $17 \mu \mathrm{g} / \mathrm{d}$ during the control diet, while levels increased to between 0.4 and $8 \mathrm{mg} / \mathrm{d}$ on the TVP diet. There was marked individual variability in metabolism of the isoflavones. Only two subjects excreted substantial levels of the metabolite, equol, while the other four subjects absorbed and excreted the precursors, daidzein and genistein (Cassidy, 1991; Cassidy et al. 1994). Quantitatively, daidzein excretion was more important than genistein and this finding has been reported also by other investigators (Kelly et al. 1993; Xu et al. 1994). Individual variability in isoflavone metabolism had been observed previously by Setchell et al. (1984). Kelly et al. (1993) also showed some individual variability in ability to deconjugate and to absorb dietary isoflavones in twelve subjects following ingestion of a $40 \mathrm{~g}$ soyabean-flour cake over two consecutive days. Inter-individual variation in isoflavone excretion between twelve female volunteers challenged for $1 \mathrm{~d}$, on three separate occasions with either $0 \cdot 7,1.3$ or $2.0 \mathrm{mg}$ isoflavones $/ \mathrm{kg}$ body weight was substantial (Xu et al. 1994).

Cassidy et al. (1994) reported an average recovery of total urinary isoflavones of between 2 and $13 \%$ of intake, following consumption of $45 \mathrm{mg}$ isoflavones/d as $60 \mathrm{~g}$ TVP. $\mathrm{Xu}$ et al. (1994) showed average $24 \mathrm{~h}$ urine recoveries of daidzein and genistein to be 21 and $9 \%$ respectively at all three doses of isoflavones. Only $1-2 \%$ of ingested isoflavones was found in faeces. No equol was detected in their urine samples. Therefore, the absorption, excretion and plasma concentrations of isoflavones may be dependent on the dose given, with urinary and plasma isoflavone levels increasing with increasing dose. At all three doses, urinary isoflavone levels were significantly greater in the first $12 \mathrm{~h}$ after 
dosing than in the subsequent $12 \mathrm{~h}$ period; plasma concentrations were significantly increased $6.5 \mathrm{~h}$ after dosing (Xu et al. 1994).

It is evident, therefore, that these compounds are absorbed. However, currently there is limited information on their bioavailability and further investigation is required to establish the reasons for the wide individual variability in excretion of these compounds.

\section{BIOLOGICAL EFFECTS IN HUMANS}

Studies by Cassidy et al. $(1994,1995)$ have examined the physiological effects of phyto-oestrogens in humans. Isoflavones, given as various soyabean products, modified hormonal status in healthy premenopausal women. Fifteen premenopausal women were studied over a 9-month period, 4-6 months of which were spent in a metabolic suite, and 2 or 3 months under closely-monitored conditions. Consumption of $45 \mathrm{mg}$ conjugated isoflavones as TVP $(60 \mathrm{~g} / \mathrm{d} ; n 6)$ over a 1 -month period significantly prolonged the length of the menstrual cycle, specifically the length of the follicular phase. The delay in menstruation was accompanied by a delay in peak luteal-phase progesterone concentrations. In addition, the mid-cycle surges of the gonadotrophins, luteinizing hormone (LH) and follicle-stimulating hormone (FSH) were suppressed $(P<0.05$ and $P<0.01$ respectively; Cassidy et al. 1994, 1995). A small number of subjects ( $n$ 3) consumed half the dose $(25 \mathrm{mg})$ as unconjugated isoflavones, $50 \mathrm{~g}$ miso/d. Similar biological effects were observed with this diet as with $45 \mathrm{mg}$ conjugated isoflavones, although the findings of the study were not statistically significant. However, peak luteal phase progesterone concentrations were significantly delayed $(P<0 \cdot 05)$. The results of these studies suggest that the chemical form of dietary isoflavones influences the observed physiological effects, with unconjugated isoflavones being potentially more efficient. None of these changes were observed when soyabean was replaced with Arcon $F$, an isoflavone-free soyabean product, in five subjects, providing convincing evidence that phyto-oestrogens are the biologically active components of soyabean products.

Several other studies with free-living subjects have examined the biological effects of phyto-oestrogens in women. Wilcox et al. (1990) supplemented the diets of a group of post-menopausal women to evaluate the oestrogenic effects of several sources of phyto-oestrogens. They showed significant changes in vaginal cytology and suppression in FSH after 6 weeks on the diet. Phipps et al. (1993) showed that $10 \mathrm{~g}$ flaxseed powder/d over three menstrual cycles in eighteen premenopausal women had little effect on their sex steroid hormone metabolism. In trials with free-living post-menopausal women, $60 \mathrm{~g}$ soyabean/d over a 4-week period suppressed LH levels, while $40 \mathrm{~g}$ linseed/d over a 6-week period caused a significant suppression of both LH and FSH (A. Cassidy, M. Faughnan, R. Hughes, C. Fraser, A. Cathcart, N. Taylor and S. Bingham, unpublished results).

These findings suggest that the phyto-oestrogens present in soyabean potentially exert a weak oestrogenic effect on the hypothalamic-pituitary-gonadal axis and potentially may be beneficial with respect to risk factors for breast cancer. Oestrogen exposure and the cumulative number of menstrual cycles a woman experiences over her premenopausal years are two important risk factors for breast cancer (Henderson et al. 1985). Mean cycle length in Western countries, where risk of breast cancer is high, is 28-29 d, while average cycle length is $32 \mathrm{~d}$ in Japan, where risk of breast cancer is 4 -fold lower (Henderson et al. 1985). Breast-cell division is 4-fold lower during the follicular 
phase of the cycle (Ferguson \& Anderson, 1981; Anderson et al. 1982), so women with longer menstrual cycles, therefore, will have longer follicular phases, resulting in reduced cell division over their premenopausal years. Tamoxifen, which is successfully used in breast-cancer therapy, at a daily dose of $20 \mathrm{mg}$, has been shown to similarly interfere with the hypothalamic-pituitary-gonadal axis, resulting in a decrease in circulating levels of LH and FSH in breast-cancer patients (Golder et al. 1976; Willis et al. 1977; Jordan et al. 1987).

Several trials have examined the biological effects of lignans in groups of free-living men. Shultz et al. (1991) showed that a daily $13.5 \mathrm{~g}$ supplement of linseed over 6 weeks had no effect on plasma testosterone, free testosterone or sex-hormone-binding globulin levels in a group of six young men. Hughes et al. (1994) showed that a higher level of linseed $(40 \mathrm{~g} / \mathrm{d})$ resulted in a significant decrease in $\mathrm{FSH}$, total cholesterol and LDL-cholesterol levels in a group of middle-aged men over 4 weeks. Although male serum testosterone and dihydrotestosterone showed a trend towards a decrease on the linseed diet there was no observed change in total urinary androgen output. Only one dietary-intervention trial with isoflavones in men has been conducted. In a group of middle-aged men $60 \mathrm{~g}$ TVP/d did not result in any significant hormonal modifications (A. Cassidy, M. Faughan, R. Hughes, C. Fraser, A. Cathcart, N. Taylor and S. Bingham, unpublished results).

\section{OTHER POTENTIAL MECHANISMS OF ACTION}

In addition to phyto-oestrogens, soyabeans contain several other potential anticarcinogens, including protease inhibitors, phytosterols, saponins and inositol hexaphosphate (Barnes et al. 1990). Substantial literature has been published on the anti-cancer activity of the Bowman-Birk trypsin inhibitor (Kennedy, 1995); however, Barnes et al. (1990) showed that autoclaved soyabean, which inactivates the trypsin inhibitor, was as effective as non-autoclaved soyabean in reducing the number of tumours in two standard experimental animal models of breast cancer. They also showed that the Bowman-Birk trypsin-inhibitor preparations typically contain high concentrations of isoflavones.

Initial interest in the role of phyto-oestrogens in cancer prevention has centred on their anti-oestrogenic effects. However, results of several in vitro studies suggest that isoflavones, specifically genistein, do not inhibit cell growth by classical anti-oestrogenic mechanisms.

At high concentrations, genistein acts as a potent inhibitor of proliferation of both oestrogen-receptor-negative and -positive breast-cancer cells (Peterson \& Barnes, 1991). Genistein also specifically inhibits the activity of the epidermal-growth-factor receptor (EGFR) tyrosine kinase with the value for the concentration required for $50 \%$ inhibition $\left(\mathrm{IC}_{50}\right)$ of about $0.7 \mu \mathrm{g} / \mathrm{ml}$. Serine and threonine kinases require concentrations $>30$ $\mu \mathrm{g} / \mathrm{ml}$ for inhibition (Akiyama et al. 1987). However, genistein does not inhibit the activation of growth-factor receptors in tumour cells, because genistein did not block EGFR autophosphorylation in DU-145 prostate cancer cell lines (Peterson \& Barnes, 1993). Neither daidzein (Sargeant et al. 1993) nor genistin (Arrora et al. 1995) exhibit anti-tyrosine kinase activity. Genistein also inhibits in vitro angiogenesis and endothelialcell proliferation (Fotsis et al. 1993). In contrast, enterolactone, equol and daidzein were twenty to fifty times less potent (Fotsis et al. 1993). This may be an important finding; however, the half-maximal effect for inhibition of angiogenesis required approximately 
$40 \cdot 5 \mu \mathrm{g}$ genistein $/ \mathrm{ml}$, which is an order of magnitude higher than the levels required to inhibit cancer-cell growth, and almost two orders of magnitude higher than estimates of blood isoflavone concentrations reported in humans consuming soyabean products.

Genistein inhibits the activity of topoisomerase II in vitro with $\mathrm{IC}_{50}$ values of approximately $30 \mu \mathrm{g} / \mathrm{ml}$ (Okura et al. 1988; Markovitz et al. 1989; Constantinou et al. 1990). Slight inhibition occurs at low genistein concentrations $(3 \mu \mathrm{g} / \mathrm{ml})$ but complete inhibition requires concentrations $>50 \mu \mathrm{g} / \mathrm{ml}$. In vitro studies also show that genistein inhibits topoisomerase II activity by stabilizing the DNA-topoisomerase II complex (Yamashita et al. 1991). Stabilization of this complex in tumour cells leads to double- and single-strand breaks in cellular DNA, leading to growth inhibition or cell death (Gerwirtz, 1991). However, at $\mathrm{IC}_{50}$ values for growth inhibition, little DNA damage is observed, suggesting that genistein does not inhibit cell growth through inhibition of topoisomerase II activity (Okura et al. 1988; Markovitz et al. 1989; Constantinou et al. 1990).

Isoflavones may exert some of their anti-cancer effects through an antioxidant mechanism. Genistein has been shown to decrease the production of reactive oxygen species (ROS) by tumour cell types and cells of the immune system. Genistein at $0 \cdot 5-8$ $\mu \mathrm{g} / \mathrm{ml}$ can directly inhibit agonist-stimulated ROS production (Akimura et al. 1992; Tanimura et al. 1992; Utsumi et al. 1992; Wei et al. 1993).

The relevance of these in vitro studies in understanding the potential chemopreventative effects of phyto-oestrogens is unknown. Many of these studies were carried out using high concentrations of phyto-oestrogens and few of the previously described mechanisms in tumour cells are sensitive to physiological serum concentrations of genistein. However, limitations in the existing analytical methods need to be resolved (K. D. R. Setchell, personal communication). For example, mean total genistein levels in plasma were $16 \mathrm{ng} / \mathrm{ml}$ in a group of vegetarians, while a group of Japanese men secreted on average $75 \mathrm{ng}$ genistein $/ \mathrm{ml}$ (Table 2), whereas concentrations used in the in vitro studies were in the microgram range.

The majority of in vitro tissue-culture experiments have been carried out with established human cancer cell lines, although these experiments will not address the role of phyto-oestrogens on normal cell proliferation. Thus, the physiological significance of the inhibitory effects of isoflavones on the growth of untransformed, normal cells needs to be examined.

\section{POTENTIAL ADVERSE EFFECTS}

In order to evaluate any potential risks offered by phyto-oestrogens, their potency and sites of action, when consumed at natural dietary concentrations, need to be investigated. Each phyto-oestrogen needs to be fully characterized in terms of its site of action, balance of agonistic and/or antagonistic properties, natural potency and short-term and long-term effects. It has been suggested that differences in sensitivity to phytooestrogens is dependent on differences in metabolism, particularly in conjugative capacity.

Phyto-oestrogens are known to induce infertility in livestock (Price \& Fenwick, 1985), so it is important to determine if there are potential effects on fertility in humans. Several studies have examined the effects of phyto-oestrogens in the reproductive tract and brain of experimental animals. These studies show that phyto-oestrogens in a similar way to 
other oestrogens, have the capacity to induce developmental toxicity, but most of these studies have concentrated on the actions of the most-potently-oestrogenic isoflavone, coumestrol (Burroughes et al. 1985, 1990; Whitten et al. 1992; Medlock et al. 1995).

It is well established that exogenous oestrogens increase the risk of endometrial cancer (Smith et al. 1975). Tamoxifen, an anti-oestrogen drug which has successfully been employed in the treatment of breast cancer, has also been associated with oestrogenic side effects, such as thrombo-embolic phenomena and endometrial proliferation in post-menopausal women (Fornander et al. 1989; Fisher et al. 1994). Phyto-oestrogens also exert partial agonist and/or partial antagonist activity, but there is insufficient epidemiological evidence to suggest that the agonist properties of the compounds may cause an increased risk of endometrial hyperplasia, or endometrial carcinoma. Miyazawa (1976) suggested that there was a high prevalence of endometriosis in Japanese women, but this finding was based on one cross-sectional study of gynaecological admissions to hospitals in Hawaii, in which fewer than four cases of endometriosis were Japanese.

\section{OTHER POTENTIAL HEALTH BENEFITS}

The physiological effects of plant oestrogens are also likely to have effects on bone metabolism and on heart disease. There is substantial evidence from studies on experimental animals and human subjects that substituting soyabean protein for animal protein in the diet reduces serum concentrations of total and LDL-cholesterol (Sirtori et al. 1993), but the mechanism by which this occurs is unknown. There are welldocumented effects of oestrogens on lipid metabolism, thus the observed effects of phyto-oestrogens in lowering blood cholesterol levels may be relevant to ischaemic heart disease, of which total cholesterol, LDL-cholesterol, and LDL-cholesterol:HDLcholesterol are known to be important risk factors (Cardiovascular Review Group Committee on Medical Aspects of Food Policy, 1994). Independent of a possible role of isoflavones in the reduction of serum cholesterol levels, limited studies of cultured vascular cells suggest that some of the cellular processes involved in lesion formation are inhibited by genistein. Genistein is a potent inhibitor of tyrosine kinase activity in vitro (Akiyama et al. 1987) and is, therefore, capable of blocking growth factor action. For example, genistein $(27 \mu \mathrm{g} / \mathrm{ml})$ inhibited platelet-derived growth factor-induced thymidine incorporation and receptor autophosphorylation (Hill et al. 1990). It has been shown also to inhibit thrombin formation, and platelet activation in vitro (Sargeant et al. 1993; Wilcox \& Blumenthal, 1995). If genistein has the same effects in vivo, this compound has the potential to slow the development or progression of atherosclerotic disease by modifying coagulation responses. However, currently this is speculative and future research should assess its potential therapeutic effects for vascular disease in vivo.

The weak oestrogenic action of isoflavones may be potentially beneficial in the prevention of osteoporosis; however, there are few studies to support this hypothesis. Anderson et al. (1995) compared the potential agonistic effects of genistein on the retention of cancellous bone tissue in rats with premarin, an oestrogen with known bone-retaining properties. Genistein at a dose of $1 \mathrm{mg} / \mathrm{d}$ had a similar effect in maintaining trabecular bone tissue to that of premarin $(5 \mu \mathrm{g} / \mathrm{d})$, but at higher doses $(3 \cdot 2$ and $10 \mathrm{mg} / \mathrm{d}$ ) it had no retentive effect on bone mass. In addition, an isoflavone derivative, ipriflavone, directly inhibited bone resorption in a human model of osteoblast (Cheng et al. 1995). 
High levels of circulating gonadotrophins have been associated with post-menopausal symptoms, e.g. hot flushes (Aitken et al. 1974; Casper et al. 1979; Tataryn et al. 1979). The observed decreases in LH and FSH levels in the free-living post-menopausal women consuming TVP and linseed (A. Cassidy, M. Faughnan, R. Hughes, C. Fraser, A. Cathcart, N. Taylor and S. Bingham, unpublished results) suggest that phyto-oestrogens have the potential to alleviate post-menopausal symptoms. Recently, Murkies et al. (1995) showed that a daily supplement of 45 g soyabean flour significantly reduced the number of hot flushes within 6 weeks in a group of post-menopausal women.

\section{CONCLUSIONS}

Epidemiological evidence, results from human and animal studies, and some in vitro work suggest that phyto-oestrogens may be protective against the development of hormone-dependent cancers. It is evident that these compounds are absorbed, and from the available data, have potential biological effects in humans. Isoflavones, $50-100 \mathrm{mg} / \mathrm{d}$, are typically consumed by humans in the Far East (Barnes et al. 1990; Adlercreutz et al. 1991; Coward et al. 1993) where hormone-dependent cancer rates are low. Phytooestrogens, therefore, may protect against hormone-dependent cancers but more research needs to be conducted.

Future research should examine the metabolism and absorption of these compounds in vivo to help explain the wide individual variability in excretion of these compounds, even under controlled dietary conditions. More feeding trials need to be conducted to examine the biological effects of lignans in humans, and to confirm the importance of the chemical form in which the isoflavones are ingested. Evidence of a direct effect at the breast or prostate needs to be demonstrated in clinical trials. The mechanisms of action of the phyto-oestrogens needs to be established by performing further in vitro studies using non-transformed normal cells at physiologically-relevant concentrations of the compounds. The biological relevance of these in vitro studies could then be predicted.

\section{REFERENCES}

Adlercreutz, H., Fotsis, T., Bannwart, C., Wahala, K., Brunow, G. \& Hase, T. (1991b). Isotope dilution gas chromatographic-mass spectrometric method for the determination of lignans and isoflavonoids in human urine, including the identification of genistein. Clinica Chimica Acta 199, 263-278.

Adlercreutz, H., Fotsis, T., Bannwart, C., Wahala, K., Makela, T., Brunow, G. \& Hase, T. (1986). Determination of urinary lignans and phytoestrogen metabolites, potential antiestrogens and anticarcinogens, in the urine of women on various habitual diets. Journal of Steroid Biochemistry 25, 791-797.

Adlercreutz, H., Fotsis, T., Heikkinen, R., Dwyer, J. T., Goldin, B. R., Gorbach, S. L., Lawson, A. M. \& Setchell, K. D. R. (1981). Diet and urinary excretion of lignans in female subjects. Medical Biology 59, 259-261.

Adlercreutz, H., Fotsis, T., Heikkinen, R., Dwyer, J. T., Woods, M., Goldin, B. R. \& Gorbach, S. L. (1982). Excretion of the lignans enterolactone and enterodiol and of equol in omnivorous and vegetarian postmenopausal women and in women with breast cancer. Lancet ii, 1295-1299.

Adlercreutz, H., Fotsis, T., Kurzer, M. S., Wahala, K., Makela, T. \& Hase, T. (1995). Isotope dilution gas chromatographic-mass spectrometric method for the determination of unconjugated lignans and isoflavonoids in human feces, with preliminary results in omnivorous and vegetarian women. Analytical Biochemistry 225, 101-108.

Adlercreutz, H., Fotsis, T., Lampe, J., Wahala, K., Makela, T., Brunow, G. \& Hase, 'T. (1993a). Quantitative determination of lignans and isoflavonoids in plasma of omnivorous and vegetarian women by isotope dilution gas chromatography-mass spectrometry. Scandinavian Journal of Clinical and Laboratory Investigation 53, Suppl. 215, 5-18. 
Adlercreutz, H., Hamalainen, E., Gorbach, S. \& Goldin, B. (1992). Dietary phyto-oestrogens and the menopause in Japan. Lancet 339, 1233.

Adlercreutz, H., Honjo, H., Higashi, A., Fotsis, T., Hamalainen, E., Hasegawa, T. \& Okada, H. (1991a). Urinary excretion of lignans and isoflavonoid phytoestrogens in Japanese men and women consuming a traditional Japanese diet. American Journal of Clinical Nutrition 54, 1093-1100.

Adlercreutz, H., Markkanen, H. \& Watanabe, S. (1993b). Plasma concentrations of phyto-oestrogens in Japanese men. Lancet 342, 1209-1210.

Aitken, J. M., Davidson, A., England, P., Govan, A. D. T., Hart, D. M., Kelly, A., Lindsay, R. \& Moffatt, A. (1974). The relationship between menopausal vasomotor symptoms and gonadotrophin excretion in urine after oophorectomy. Journal of Obstetrics and Gynaecology 81, 150-154.

Akiyama, T., Ishida, J., Nakagava, S., Ogawara, S., Watanabe, S., Itoh, N., Shiyba, M. \& Fukami, Y. (1987). Genistein, a specific inhibitor of tyrosine-specific protein kinases. Journal of Biological Chemistry 262, 5592-5595.

Akiyama, K., Utsumi, T., Sato, E. F., Klostergaard, J., Inoue, M. \& Utsumi, K. (1992). Role of tyrosyl phosphorylation in neutrophil priming by tumour necrosis factor- $\alpha$ and granulocyte colony stimulating factor. Archives of Biochemistry and Biophysics 298, 703-709.

Anderson, J. J., Ambrose, W. W. \& Garner, S. C. (1995). Orally dosed genistein from soy and prevention of cancellous bone loss in two ovariectomized rat models. Journal of Nutrition 125, $799 \mathrm{~S}$ Abstr.

Anderson, T. J., Ferguson, D. J. P. \& Raab, G. M. (1982). Cell turnover in the 'resting' human breast: influence of parity, contraceptive pill, age and laterality. British Journal of Cancer 46, 376.

Arora, P. D., Ma, J., Min, W., Cruz, A. \& McCulloch, C. A. G. (1995). Interleukin-1-induced calcium flux in human fibroblasts is mediated through focal adhesions. Journal of Biological Chemistry 270, 6042-6049.

Axelson, M. \& Setchell, K. D. R. (1980). Conjugation of lignans in human urine. FEBS Letters 122, 45-53.

Axelson, M., Sjovall, J., Gustafsson, B. E. \& Setchell, K. D. R. (1982). Origin of lignans in mammals and identification of a precursor from plants. Nature 298, 659-660.

Barnes, S., Grubbs, C., Setchell, K. D. R. \& Carlson, J. (1990). Soyabeans inhibit mammary tumor growth in models of breast cancer. In Mutagens and Carcinogens in the Diet, pp. 239-253 [M. W. Pariza, editor]. New York: Wiley-Liss.

Bennetts, H. W., Underwood, E. J. \& Shier, F. L. (1946). A specific breeding problem of sheep on subterranean clover pastures in Western Australia. Australian Veterinary Journal 22, 2-12.

Burroughes, C. D., Mills, K. T. \& Bern, H. A. (1985). Prolonged vaginal cornification and other changes in mice treated neonatally with coumestrol, a plant estrogen. Journal of Toxicology and Environmental Health 15, 51-61.

Burroughes, C. D., Mills, K. T. \& Bern, H. A. (1990). Long-term genital tract changes in female mice treated neonatally with coumestrol. Reproductive Toxicology 4, 127-135.

Cardiovascular Review Group Committee on Medical Aspects of Food Policy (1994). Nutritional Aspects of Cardiovascular Disease. London: H.M. Stationery Office.

Casper, R. F., Yen, S. S. C. \& Wilkes, M. M. (1979). Menopausal flushes: a neuroendocrine link with pulsatile luteinising hormone secretion. Science $205,823-825$.

Cassidy, A. (1991). Plant oestrogens and their relation to hormonal status in women. PhD Thesis, University of Cambridge.

Cassidy, A., Bingham, S. \& Setchell, K. (1994). Biological effects of isoflavones present in soy in premenopausal women: Implications for the prevention of breast cancer. American Journal of Clinical Nutrition 60, 333-340.

Cassidy, A., Bingham, S. \& Setchell, K. (1995). Biological effects of isoflavones in young women: importance of the chemical composition of soyabean products. British Journal of Nutrition 74, 587-601.

Cassidy, A., Bingham, S., Setchell, K. \& Watson, D. (1990). Plant oestrogen excretion in a group of postmenopausal women. Proceedings of the Nutrition Society 50, 105A.

Cheng, S. L., Zhang, S. F., Nelson, T. L., Warlow, P. M. \& Civitelli, R. (1995). Stimulation of human osteoblast differentiation and function by ipriflavone and its metabolites. Calcified Tissue International 55, $356-362$.

Clevenger, S. (1964). Flower pigments. Scientific American 210, 84-92.

Constantinou, A., Kiguchi, K. \& Huberman, E. (1990). Induction of differentiation and strand breakage in human HL-60 and K-562 leukemia cells by genistein. Cancer Research 50, 2618-2624.

Coward, L., Barnes, N. C., Setchell, K. D. R. \& Barnes, S. (1993). The isoflavones genistein and daidzein in soy based foods from American and Asian diets. Journal of Agriculture and Food Science 41, 1961-1967. 
Dehennin, L., Reiffsteck, A., Jondet, M. \& Thiber, M. (1982). Identification and quantitative estimation of a lignan in human and bovine semen. Journal of Reproduction and Fertility 66, 305-309.

Ferguson, D. J. P. \& Anderson, T. J. (1981). Morphological evaluation of cell turnover in relation to the menstrual cycle in the 'resting' human breast. British Journal of Cancer 44, 177-181.

Finlay, E. M. H., Wilson, D. W., Adlercreutz, H. \& Griffiths, K. (1991). The identification and measurement of 'phyto-oestrogens' in human saliva, plasma, breast aspirate or cyst fluid, and prostatic fluid using gas chromatography-mass spectrometry. Journal of Endocrinology 129, Suppl., 49 Abstr.

Fisher, B., Costantino, J. P., Redmond, C. D., Fisher, E. R., Wickerham, D. L. \& Cronin, W. M. (1994). Endometrial cancer in tamoxifen-treated breast cancer patients: findings from the National Surgical Adjuvant Breast and Bowel Project (NSABP) B-14. Journal of the National Cancer Institute 865, 527-537.

Fornander, T., Rutqvist, L. E. \& Cedermark, B. (1989). Adjuvant tamoxifen in early breast cancer, occurrence of new primary cancers. Lancet $\mathbf{i}, 117$.

Fotsis, T., Heikkinen, R., Adlercreutz, H., Axelson, M. \& Setchell, K. D. R. (1982). Capillary gas chromatographic method for the analysis of lignans in human urine. Clinica Chimica Acta 121, 361-371.

Fotsis, T., Pepper, M., Adlercreutz, H., Fleischmann, G., Hase, T., Montesano, R. \& Schweigerer, L. (1993). Genistein, a dietary-derived inhibitor of angiogenesis. Proceedings of the National Academy of Sciences, USA 90, 2690-2694.

Francis, C. M. \& Hume, I. D. (1971). The relationship between lignification and flavonoid production in subterranean clover. Australian Journal of Biological Science 24, 1-5.

Gerwirtz, D. A. (1991). Does bulk damage to DNA explain the cytostatic effects of topoisomerase II inhibitors. Biochemical and Biophysical Research Communications 42, 2253-2258.

Golder, M. P., Phillips, E. A., Fahmy, D. R., Preece, P. E., Jones, V., Henk, J. M. \& Griffiths, K. (1976). Plasma hormones in patients with advanced breast cancer treated with Tamoxifen. European Journal of Cancer 12, 719-723.

Hanson, C. H., Loper, G. M., Kohler, G. O., Bickoff, E. M., Taylor, K. W., Kehr, W. R., Stanford, E. H., Dudley, J. W., Pedersen, M. W., Sorensen, E. L., Carnahan, H. L. \& Wilsie, C. P. (1965). Variation in coumestrol content of alfalfa, as related to location, variety, cutting, year, stage of growth and disease. United States Department of Agriculture, Agricultural Research Service technical bulletin no. 1333, pp. 1-72. Washington, DC: US Department of Agriculture, Agricultural Research Service.

Haworth, R. D. \& Slinger, F. H. (1940). The constituents of natural phenolic resins. Part XVII. A synthesis of 1-matairesinol. Journal of the Chemical Society 1098-1101.

Hawrylewicz, E. J., Huang, H. H. \& Blair, W. H. (1991). Dietary soya bean isolate and methionine supplementation affect mammary tumour progression in rats. Journal of Nutrition 121, 1693-1698.

Henderson, B. E., Ross, R. K., Judd, H. L., Krailo, M. D. \& Pike, M. C. (1985). Do regulatory ovulatory cycles increase breast cancer risk? Cancer 56, 1206-1208.

Hill, T. D., Dean, N. M., Mordan, L. J., Lau, A. F., Kanemitsu, M. Y. \& Boynton, A. L. (1990). PDGF-induced activation of phospholipase $C$ is not required for induction of DNA synthesis. Science 248, $1660-1663$.

Hirayama, T. (1979). Epidemiology of prostate cancer with special reference to the role of diet. National Cancer Institute Monograph 53, 149-155.

Hirayama, T. (1986). A large scale cohort study on cancer risks by diet - with special reference to the risk reducing effects of green-yellow vegetable consumption. In Diet, Nutrition and Cancer, pp. 41-53 [Y. Hayashi, M. Nagao, T. Sugimura, S. Takayama, L. Tomatis, L. W. Wattenberg and G. N. Wogan, editors]. Tokyo: Japanese Scientific Society Press.

Hirohata, T., Shigematsu, T., Nomura, A. M. Y. \& Horie, A. (1985). Occurrence of breast cancer in relation to diet and reproductive history: A case-control study in Fukuoka, Japan. National Cancer Institute Monograph 69, 187-190.

Hughes, R., Cassidy, A. \& Bingham, S. (1994). Hormonal effects of lignans in a group of men. Proceedings of the Nutrition Society 53, $230 \mathrm{~A}$.

Jones, A. E., Price, K. R. \& Fenwick, G. R. (1989). Development and application of a high-performance liquid chromatographic method for the analysis of phytoestrogens. Journal of the Science of Food and Agriculture 46, 357-364.

Jordan, V. C. (1990). The only true antiestrogen is a no estrogen. Molecular and Cellular Endocrinology 74, C91.

Jordan, V. C., Fritz, N. F. \& Tormey, D. C. (1987). Endocrine effects of adjuvant chemotherapy and long-term Tamoxifen administration on node-positive patients with breast cancer. Cancer Research 47, $624-630$. 
Juniewicz, P. E., Pallante Morell, S., Moser, A. \& Ewing, L. L. (1988). Identification of phytoestrogens in the urine of male dogs. Journal of Steroid Biochemistry 31, 987-994.

Kelly, G. E., Nelson, C., Waring, M. A., Joannou, G. E. \& Reeder, A. Y. (1993). Metabolites of dietary (soya) isoflavones in human urine. Clinica Chimica Acta 223, 9-22.

Kennedy, A. R. (1995). The evidence of soybean products as cancer prevention agents. Journal of Nutrition $125,733 \mathrm{~S}-743 \mathrm{~S}$.

Lamartiniere, C. A., Moore, J., Holland, M. B. \& Barnes, S. (1995). Neonatal genistein chemoprevents mammary carcinogenesis. Proceedings of the Society for Experimental Biology and Medicine 208, 120-123.

Lee, H. P., Gourley, L., Duffy, S. W., Esteve, J., Lee, J. \& Day, N. E. (1991). Dietary effects on breast cancer risk in Singapore. Lancet 337, 1197-1200.

Makela, S. I., Pylkkanen, L. H., Santti, R. S. S. \& Adlercreutz, H. (1995). Dietary soybean may be antiestrogenic in male mice. Journal of Nutrition 125, 437-445.

Markovitz, J., Linassier, C., Fosse, P., Couprie, J., Jaquemin-Sablon, A., Pecq, J. B. \& Larson, A. K. (1989). Inhibitory effects of the tyrosine kinase inhibitor genistein on mammalian DNA topoisomerase II. Cancer Research 49, 5111-5117.

Martin, P. M., Horwitz, K. B., Ryan, D. S. \& McGuire, W. L. (1978). Phytoestrogens interaction with estrogen receptors in human breast cancer cells. Endocrinology 103, 1860-1867.

Medlock, K. L., Branham, W. S. \& Sheehan, D. M. (1995). Effects of coumestrol and equol on the developing reproductive tract of the rat. Proceedings of the Society for Experimental Biology and Medicine 208, 67-71.

Messina, M. J., Persky, V., Setchell, K. D. R. \& Barnes, S. (1994). Soy intake and cancer risk: A review of the in vitro and in vivo data. Nutrition and Cancer 21, 113-131.

Miyazawa, K. (1976). Incidence of endometriosis among Japanese women. Obstetrics and Gynaecology 48, 407-409.

Morley, F. H. \& Francis, C. M. (1968). Varietal and environmental variations in isoflavone concentrations in subterranean clover. Australian Journal of Agricultural Science 19, 15-26.

Morton, M. S., Wilcox, G., Wahlquist, M. L. \& Griffiths, K. (1994). Determination of lignans and isoflavonoids in human female plasma following dietary supplementation. Journal of Endocrinology 142, 251-259.

Muir, C., Waterhouse, J., Mack, T., Powell, J. \& Whelan, S. (1987). Cancer Incidence in Five Continents, vol. 5, International Agency for Research on Cancer Scientific Publication no. 88. Lyon, France: IARC Scientific Publications.

Murkies, A. L., Lombard, C., Strauss, B. J. G., Wilcox, G., Burger, H. G. \& Morton, M. S. (1995). Dietary flour supplementation decreases postmenopausal hot flushes - effect of soy and wheat. Maturitas 21, 189-195.

Naim, M., Gestetner, B., Zilkah, S., Birk, Y. \& Bondi, A. (1974). Soybean isoflavones. Characterisation, determination and antifungal activity. Journal of Agricultural and Food Chemistry 22, 169-170.

Nomura, A., Henderson, B. E. \& Lee, J. (1978). Breast cancer and diet among the Japanese in Hawaii. American Journal of Clinical Nutrition 31, 2020-2025.

Oishi, K., Okada, K., Yoshida, O., Yamabe, H., Ohno, Y., Hayes, R. B. \& Schroeder, F. H. (1988). A case-control study of prostatic cancer with reference to dietary habits. Prostate 12, 179-190.

Okura, A., Arakawa, H., Oka, H., Yoshinara, T. \& Monden, Y. (1988). Effect of genistein on topoisomerase activity and on the growth of (Val 12) Ha-ras-transformed NIH 3 T3 cells. Biochemical and Biophysical Research Communications 157, 183-189.

Peterson, G. \& Barnes, S. (1991). Genistein inhibition of the growth of human breast cancer cells independence from estrogen receptors and multidrug resistance gene. Biochemical and Biophysical Research Communications 179, 661-667.

Peterson, G. \& Barnes, S. (1993). Isoflavones inhibit growth of human prostate cancer cell lines without inhibiting epidermal growth factor receptor phosphorylation. Prostate 22, 335-345.

Phipps, W. R., Martini, M. C., Lampe, J. W., Slavin, J. L. \& Kurzer, M. S. (1993). Effect of flaxseed ingestion on the menstrual cycle. Journal of Clinical Endocrinology and Metabolism 77, 1215-1219.

Price, K. R. \& Fenwick, G. R. (1985). Naturally occurring oestrogens in foods - A review. Food Additives and Contaminants 2, 73-106.

Rao, C. B. S. (1978). The Chemistry of Lignans. Waltair, India: Andhra University Press.

Sargeant, P., Farndale, R. W. \& Sage, S. O. (1993). The tyrosine kinase inhibitors methyl 2,5-dihydroxycinnimate and genistein reduce thrombin-evoked tyrosine phosphorylation and $\mathrm{Ca} 2+$ entry in human platelets. FEBS Letters 315, 242-246. 
Setchell, K. D. R. (1985). Naturally occurring non-steroid estrogens of dietary origin. In Estrogens in the Environment II, Influences on Development, pp. 69-86 [J. A. MacLachan, editor]. New York: Elsevier.

Setchell, K. D. R., Borriello, S. P., Hulme, P. \& Axelson, M. (1984). Nonsteroidal estrogens of dietary origin: possible roles in hormone-dependent disease. American Journal of Clinical Nutrition 40, 569-578.

Setchell, K. D. R., Gosselin, S. J., Welsh, M., Johnston, J. O., Balistreri, W. F., Kramer, L. W., Dresser, B. L. \& Tarr, M. J. (1987a). Dietary oestrogens - a probable cause of infertility and liver disease in captive cheetah. Gastroenterology 93, 225-233.

Setchell, K. D. R., Lawson, A. M., Conway, E., Taylor, N. F., Kirk, D. N., Cooley, G., Farrant, R. D., Wynn, S. \& Axelson, M. (1981). The definitive identification of the lignans trans-2,3-bis(3-hydroxybenzyl)y-butyrolactone and 2,3-bis(3-hydroxybenzyl)-butane-1,4-diol in human and animal urine. Biochemical Journal 197, 447-458.

Setchell, K. D. R., Lawson, A. M., McLaughlin, L. M., Patel, S., Kirk, D. N. \& Axelson, M. (1983). Measurement of enterolactone and enterodiol, the first mammalian lignans, using stable isotope dilution and gas chromatography. Biomedical Mass Spectrometry 10, 227-235.

Setchell, K. D. R., Welsh, M. \& Lim, C. K. (1987b). High-performance liquid chromatographic analysis of phytoestrogens in soy protein preparations with ultraviolet, electrochemical and thermospray mass spectrometric detection. Journal of Chromatography 386, 315-323.

Severson, R. K., Nomura, A. M. Y., Grove, J. S. \& Stemmermann, G. N. (1989). A prospective study of demographics, diet and prostate cancer among men of Japanese ancestry in Hawaii. Cancer Research 49, $1857-1860$.

Sharma, O. P., Adlercreutz, H., Strandberg, J. D., Zirkin, B. R. \& Coffey, D. S. (1992). Soy of dietary source plays a preventative role against the pathogenesis of prostatitis in rats. Journal of Steroid Biochemistry and Molecular Biology 43, 557-564.

Shultz, T. D., Bonorden, W. R. \& Seaman, W. R. (1991). Effect of short term flaxseed consumption on lignan and sex hormone metabolism in men. Nutrition Research 11, 1089-1100.

Shutt, D. A. (1976). The effect of plant oestrogens on animal reproduction. Endeavour 35, 110-113.

Shutt, D. A. \& Cox, R. I. (1972). Steroid and phytoestrogen binding to sheep uterine receptors in vitro. Journal of Endocrinology 52, 299-310.

Sirtori, C. R., Even, R. \& Lovati, M. R. (1993). Soyabean protein diet and plasma cholesterol: From therapy to molecular mechanisms. Annals of the New York Academy of Sciences 676, 188-201.

Simith, D. C., Prentice, R. \& Thompson, D. J. (1975). Association of exogenous estrogen and endometrial carcinoma. New England Journal of Medicine 293, 1164-1167.

Tanimura, M., Kobuchi, H., Utsumi, T., Yoshioka, T., Kataoka, S., Fujita, Y. \& Utsumi, K. (1992). Neutrophil priming by granulocyte colony stimulating factor and its modulation by protein kinase inhibitors. Biochemical Pharmacology 44, 1045-1052.

Tataryn, I. V., Meldrum, D. R., Lu, K. H., Frumar, A. M. \& Judd, H. L. (1979). LH, FSH and skin temperature during the menopausal hot flush. Journal of Clinical Endocrinology and Metabolism 49, $152-154$.

Thompson, L. U., Robb, P., Serraino, M. \& Cheung, F. (1991). Mammalian lignan production from various foods. Nutrition and Cancer 16, 43-52.

Troll, W., Wiesner, R., Shellabarger, C. J., Holtzman, S. \& Stone, J. P. (1980). Soybean diet lowers breast tumour incidence in irradiated rats. Carcinogenesis 1, 469-472.

Utsumi, T., Klostergard, J., Akimura, K., Edashige, K. \& Sato, E. F. (1992). Modulation of TNF-alphapriming and stimulation dependent superoxide generation in human neutrophils by protein kinase inhibitors. Archives of Biochemistry and Biophysics 294, 271-278.

Verdeal, K., Brown, R. R., Richardson, T. \& Ryan, D. S. (1980). Affinity of phytoestrogens for estradiol-binding proteins and effect of coumestrol on growth of 7,12-dimethylbenz( $\alpha$ ) anthracene-induced rat mammary tumors. Journal of the National Cancer Institute 64, 285-290.

Wei, H., Wei, L., Frenkel, K., Bowen, R. \& Barnes, S. (1993). Inhibition of tumour-promoter induced hydrogen peroxide formation by genistein in vitro and in vivo. Nutrition and Cancer 20, 1-12.

Whitten, P. L., Lewis, C. \& Naftolin, F. (1992). A phytoestrogen diet induces the premature anovulatory syndrome in lactationally exposed female rats. Biology of Reproduction 49, 1117-1121.

Wilcox, G., Wahlquist, M. L., Burger, H. G. \& Medley, G. (1990). Oestrogen effects of plant derived foods in postmenopausal women. British Medical Journal 301, 905-906.

Wilcox, J. N. \& Blumenthal, B. F. (1995). Thrombotic mechanisms in atherosclerosis: Potential impact of soy proteins. Journal of Nutrition 125, 631S-638S. 
Willis, K. J., London, D. R., Ward, H. W. C., Butt, W. R., Lynch, S. S. \& Rudd, B. T. (1977). Recurrent breast cancer treated with the antiestrogen tamoxifen: correlation between hormonal changes and clinical course. British Medical Journal i, 425-428.

Xu, X., Wang, H.-J., Murphy, P. A., Cook, L. \& Hendrich, S. (1994). Daidzein is a more bioavailable soymilk isoflavone than is genistein in adult women. Journal of Nutrition 124, 825-832.

Yamashita, Y, Kawada, S. \& Nakano, H. (1991). Induction of mammalian topoisomerase II dependent DNA cleavage by non-intercalative flavonoids genistein and orobol. FEBS Letters 288, 46-50.

Yuan, M.-J., Wang, Q.-S., Ross, R. K., Henderson, B. E. \& Yu, M. C. (1995). Diet and breast cancer in Shanghai and Tianjin, China. British Journal of Cancer 71, 1353-1358. 